\author{
Maciej Kruszyna \\ Dr hab. inż., Prof. PWr \\ Politechnika Wrocławska \\ Wydział Budownictwa Lądowego i Wodnego \\ Katedra Dróg, Mostów, Kolei i Lotnisk \\ ORCID: 00-0001-8876-6307 \\ maciej.kruszyna@pwr.edu.pl
}

DOI: 10.35117/A_ENG_21_08_02

\title{
The concept of the extension of the railway overpass in the central part of WWK
}

\begin{abstract}
The Wrocław Railway Node (WWK) was briefly characterized in the introduction to the paper. The attention to the need to increase the level of rail use in servicing city traffic in Wrocław was drawn too. Reference was made to the original proposals of the agglomeration railway system for Wrocław. The scope of necessary investment and non-investment activities was analyzed in order to increase the capacity of the cross-city railway route and the adjacent routes. It was proposed to build the fourth track on the south side of the overpass of Wrockaw railway diameter and new stops "Świdnicka" and "Grabiszyńska". In the conclusion, the need to create a second railway tunnel diameter in the longer term was signaled.
\end{abstract}

Keywords: Agglomeration railway; Cross-city route; Railway overpass; WWK (Wrocław Railway Node)

\section{Introduction}

Railways serving passenger traffic in urbanized areas may operate under different names: city railways, agglomeration railways, LRT, "S-Bahn", etc. Regardless of the name, they will be used for short-distance journeys, but with high intensity (expressed by a significant number of passengers, frequency of courses). This requires specific routing, the desired separation from the traffic of other trains, densely placed stops, and their integration with other modes of transport. In agglomeration rail networks (hereinafter referred to as KA), it is advisable to create a cross-diameter route (or several diameters) in order to concentrate transport and intensify the offer. The article discusses the concept of extending the railway flyover located in the central part of the Wrocław Railway Junction (hereinafter: WWK) in order to separate tracks for KA and thus enable the introduction of regular and frequent local train traffic.

WWK includes several railway lines running through Wrocław or in its vicinity. The scope of a node may be defined in various ways (depending on the study and its goals). An example of the area limitation is given in the terms of the contract ordered in 2019 by PLK [10]. The range of the node considered there is shown in Figure 1. The question that remains open is whether the KA should serve the entirety of the presented area, and in particular its parts far away from the agglomeration core. Regardless of the fact whether the entire WWK and KR (regional rail) segments will be separated and what the rules of coexistence of these segments 
will be, there will be an overlap of routes and courses in the central part of the node, which will mean a need for a functional diameter.

Many concepts of KA routes (and similar, otherwise called) have been developed within WWK. Their extensive review can be found, among others, in the book [5], the report [4], and in [7]. Without prejudging the final (optimal) number of lines and routes, one should take into account their large number in the central part of the junction, especially on the cross-city route. It seems reasonable to plan the transformations or the creation of the diameter in the direction of ensuring the transport capacity (throughput) enabling the planned number of trips (of course with a reserve capacity). Although "alternative" solutions are proposed, such as running some routes with alternative lines, it will be more effective to introduce as many trains as possible to a modified diameter. In the case of WWK, various variants of "diameter modification" are considered, including tunnel solutions $[2,3]$. As the primary and economically feasible, it is proposed to extend the railway flyover from a three-track to a four-track cross-section.

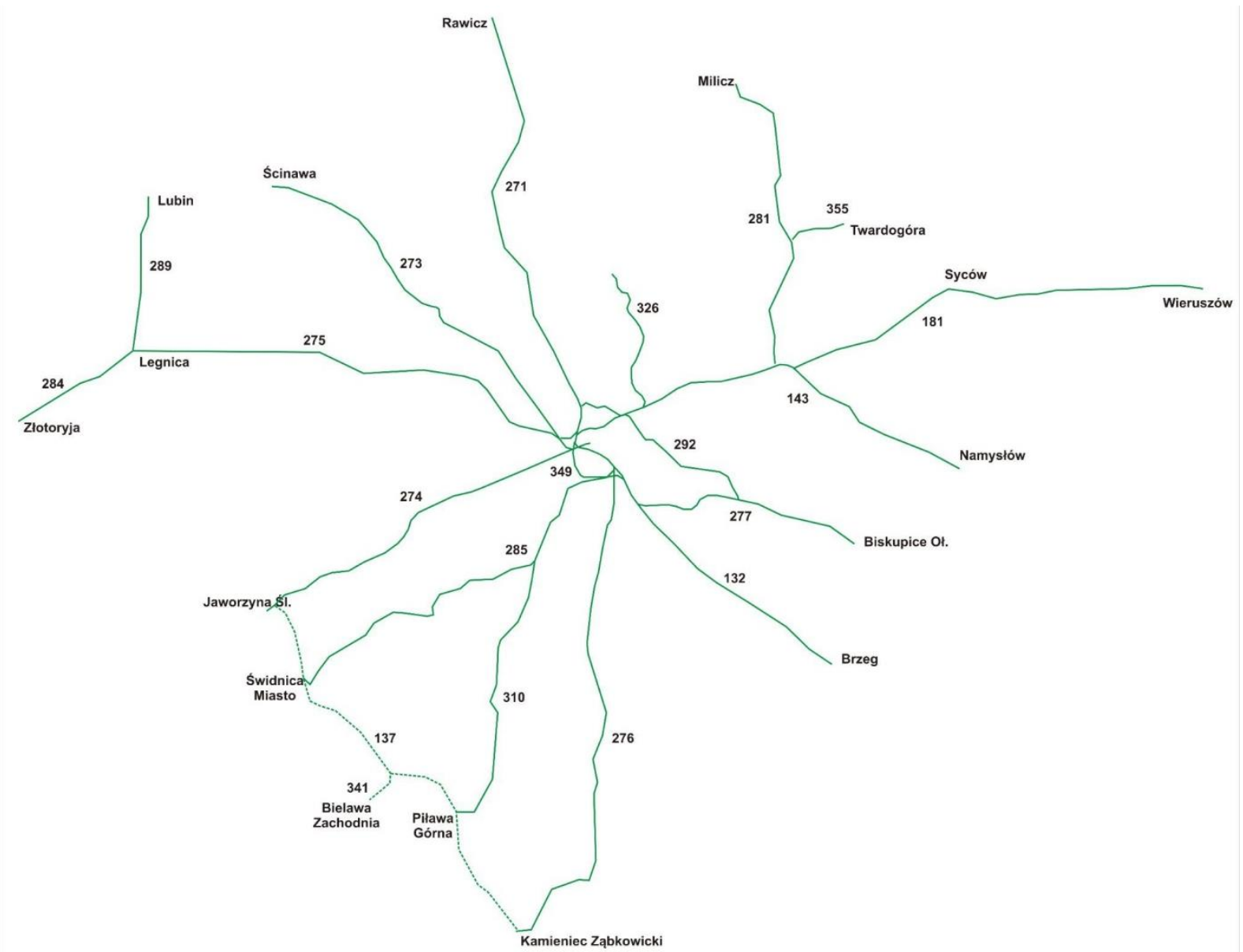

1. WWK according to [10] with the numbering of the most important railway lines

\section{The role of diameter in the KA concept}

The concept of CA in WWK, described below, was proposed (as one of the variants) and described in [4]. It includes specific parameters for individual routes. The KA network reaches places within a 30-minute drive to the center. Ultimately, there are 6 cross-city lines connecting 6 towns from the west and east of the Wrocław Główny railway station (WG). The implementation of such a network requires the reactivation of the routes to Sobótka and Jordanów Śl. through Kobierzyce and the line from Jelcz Laskowice to Wrocław Sołtysowice on the northern side of the Odra (plus a chord). In order to balance the number of lines reaching the WG station from both sides, it is proposed to build a chord between lines 292 and 277, also 
to enable the agglomeration line to be routed from the northern part of the Czernica commune along a shorter route to the center of Wrocław (runs from the Soltysowice station). The layout of routes described above, with selected (the most important stops) marked, is shown in Figure 2. In addition to the 6 diameter routes discussed here, the figure shows a potential "airport" line (black) with a less regular service system (adapted to the flight schedule).

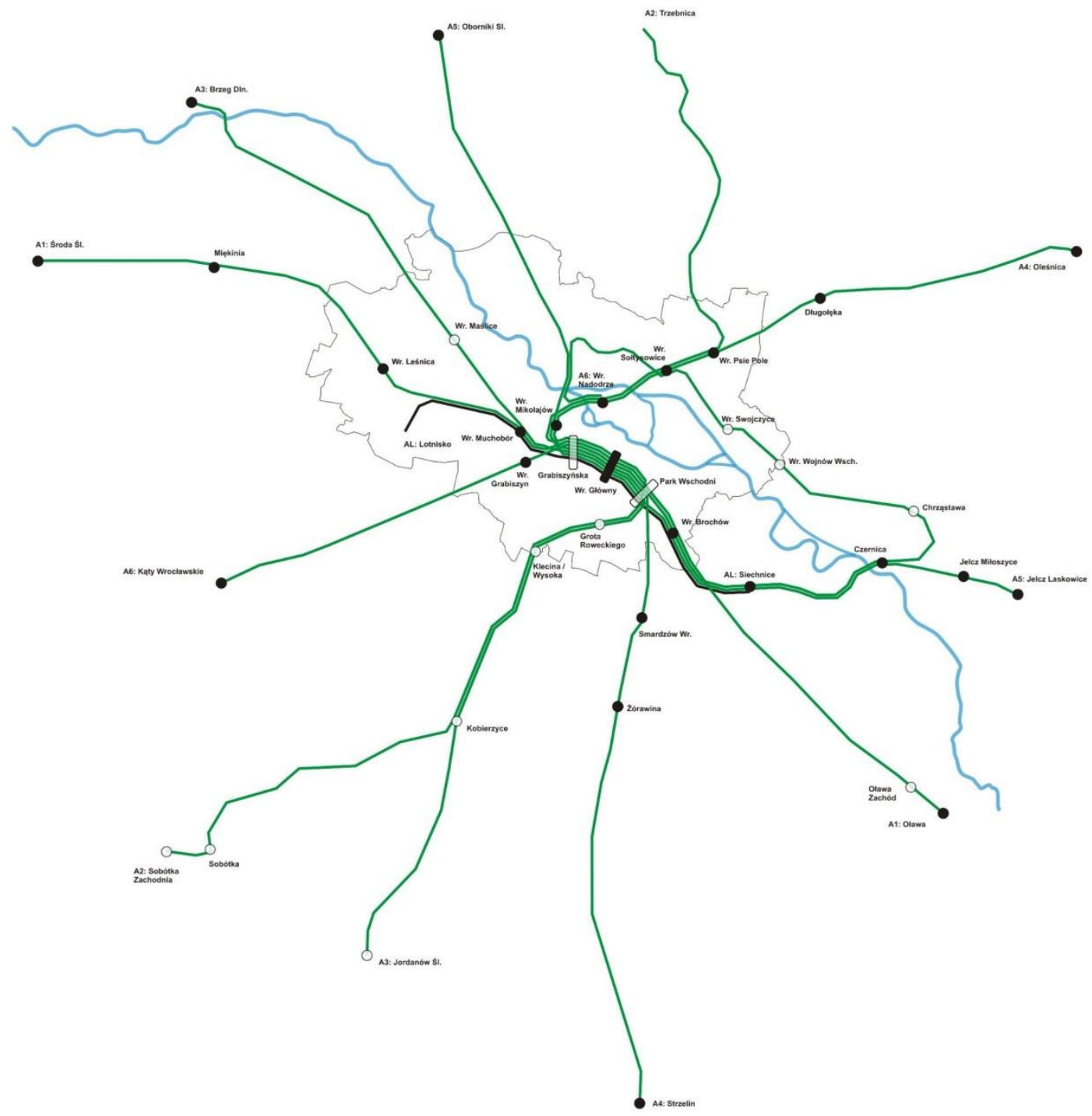

2. Proposed system of 6 diameter KA routes plus an airport line

The ends of the agglomeration railway line are located within 30 minutes from the center of Wrocław. This allows to optimize the use of the rolling stock (one train on the cross-city line takes up to 2 hours to travel, so 4 trains are required for a 30-minute cycle time, and 6 for a 20minute cycle). More distant stations are intended to be serviced by regional lines. With the assumed number of routes using the diameter (6) and peak cycles for each route (30 or 20 minutes), the resulting traffic load is: 12 or 18 trains per hour and direction (i.e. an average ride every 5 minutes or 3 minutes and 20 seconds). It is also important to plan 2 stops for KA on the diameter between the Main Railway Station and the branch post Grabiszyn. The diameter with the stops are shown in Figure 3.

For directions extending beyond the agglomeration area, several target stations can be indicated. This shows the flexible possibility of configuring the courses. It is important to coordinate transport on agglomeration and regional lines according to the principles described 
above. The end station for the agglomeration line (and the transfer station for the regionagglomeration relationship) can also be located in various ways. The choice of the station may be determined by the infrastructure enabling the return of the train (existing or planned) or the importance (size) of a given locality in the agglomeration transport system. For example, for the line to Środa Śląska, there is another option to terminate the line. It is postulated to extend the line (construction of a section bringing public transport closer to the town center). Today's Środa Śl. except that the agglomeration line would not end there, but would continue a bit further to the Środa Śl. City. Such a station and the track leading to it existed in Środa Śl. until the 1960s. Rebuilding the track on the former track may encounter ownership obstacles, but it is possible to route a new track with a similar route. The development of the network similar to the one outlined above is also possible in other places of the network (e.g. in Oleśnica).

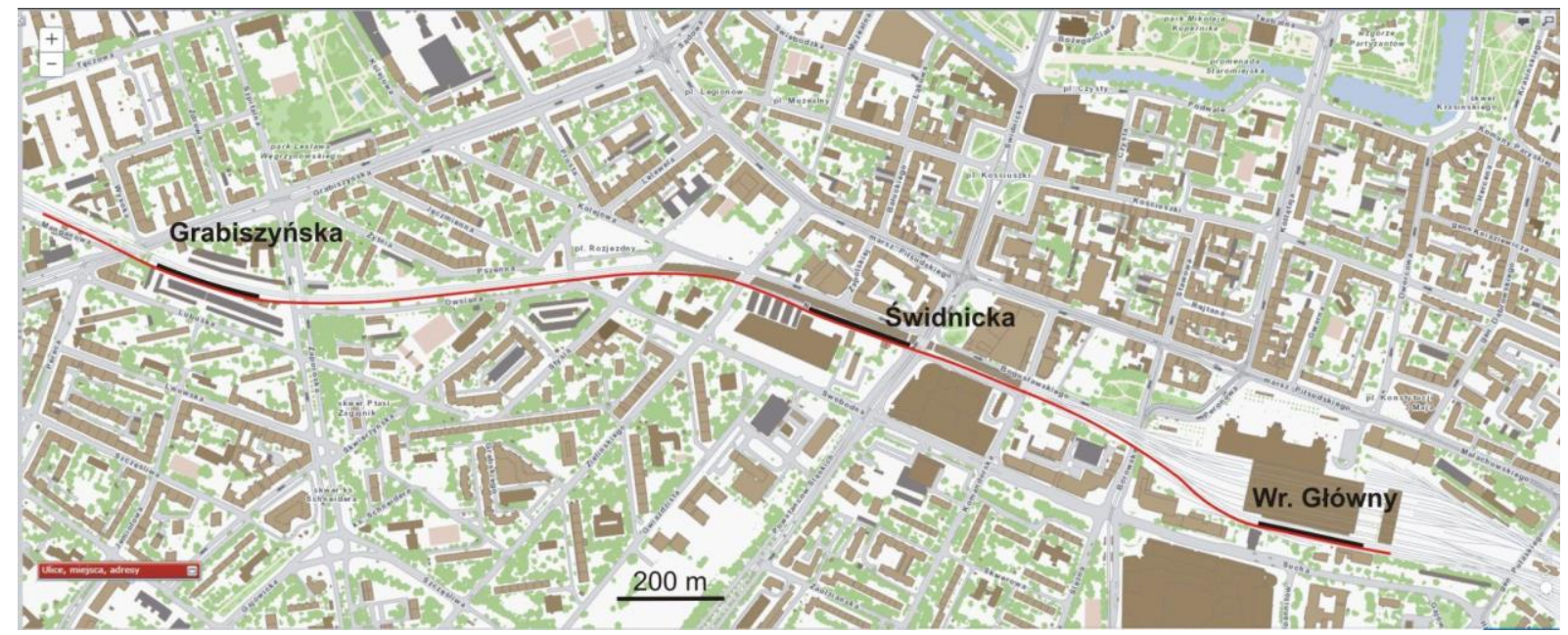

3. Diameter with stops' spacing (map source: http://gis.um.wroc.pl/)

Possibility of increasing the capacity of the cross-city route and adjacent routes indicators If you want to achieve a 20-minute cycle, you will not avoid the necessity to make some point or section investments in infrastructure [8]. The necessary investments are included in the agenda. The tasks for the option denoting the development of the diameter based on the existing flyover and its surroundings are numbered from 1 to 10 (see Figure 4).

1. Reconstruction of track heads of WG stations on both sides in order to allow KA trains to stop at the current platforms 5 and 6 (or the newly built island double-edge platform 5),

2. Collision-free running of two tracks intended only for KA trains above or below the tracks connecting platforms $1-4$ of WG stations with the tracks of the depot and locomotive shed (in order to avoid a collision between KA trains traffic and the traffic of long-distance trains and KR trains being put or put away),

3. On the section WG - a planned new stop Wr. Armii Krajowej (located under the viaduct along the same street) tracks 203 and 204 will be used only for KA trains, while tracks 201 and 202 - for long-distance trains and KR, both for line 132 ("Opolska") and 276 ("Strzelin"),

4. The collision-free track layout for KA trains in relation to tracks for long-distance and KR trains between the planned new stop Wr. Armii Krajowej, and the splitting of lines 132, 276, and 285 (the area of the viaducts along Gazowa - Karwińska Streets),

5. The construction of the fourth track along the branch post Wroclaw Grabiszyn - WG and the designation of one pair of tracks only for the traffic of KA trains, and the other - for the traffic of long-distance and KR trains, 
6. Collision-free route of two tracks intended exclusively for KA trains over branch post Wr. Grabiszyn (in order to avoid a collision between KA trains traffic and long-distance and KR train traffic), correction of the track system branch post Wr. Grabiszyn

7. Construction of 2 new tracks for KA trains only, on the branch post Grabiszyn Wroclaw Mikołajów,

8. Collision-free track layout for trains "from Nadodrze" (line 143) in relation to trains "to Poznań" (line 271) between the station Wr. Mikołajów and the divergence of lines 271 and 143 (the area of the viaducts over the streets: Ścinawska, Starograniczna Gnieźnieńska),

9. Adding additional tracks to avoid Wr. Mikołajów,

10. The construction of a second track for KA trains along the slip road no. 757 (between the Wr. Muchobór station and the proposed "Góralska" interchange) - this is a task only in the case of reactivation of rail traffic also towards the Wrocław Świebodzki station [9].

The location of these investment tasks is shown schematically in Fig. 4. The study [4] estimated the cost of the proposed investments, but it goes beyond the scope of this article.

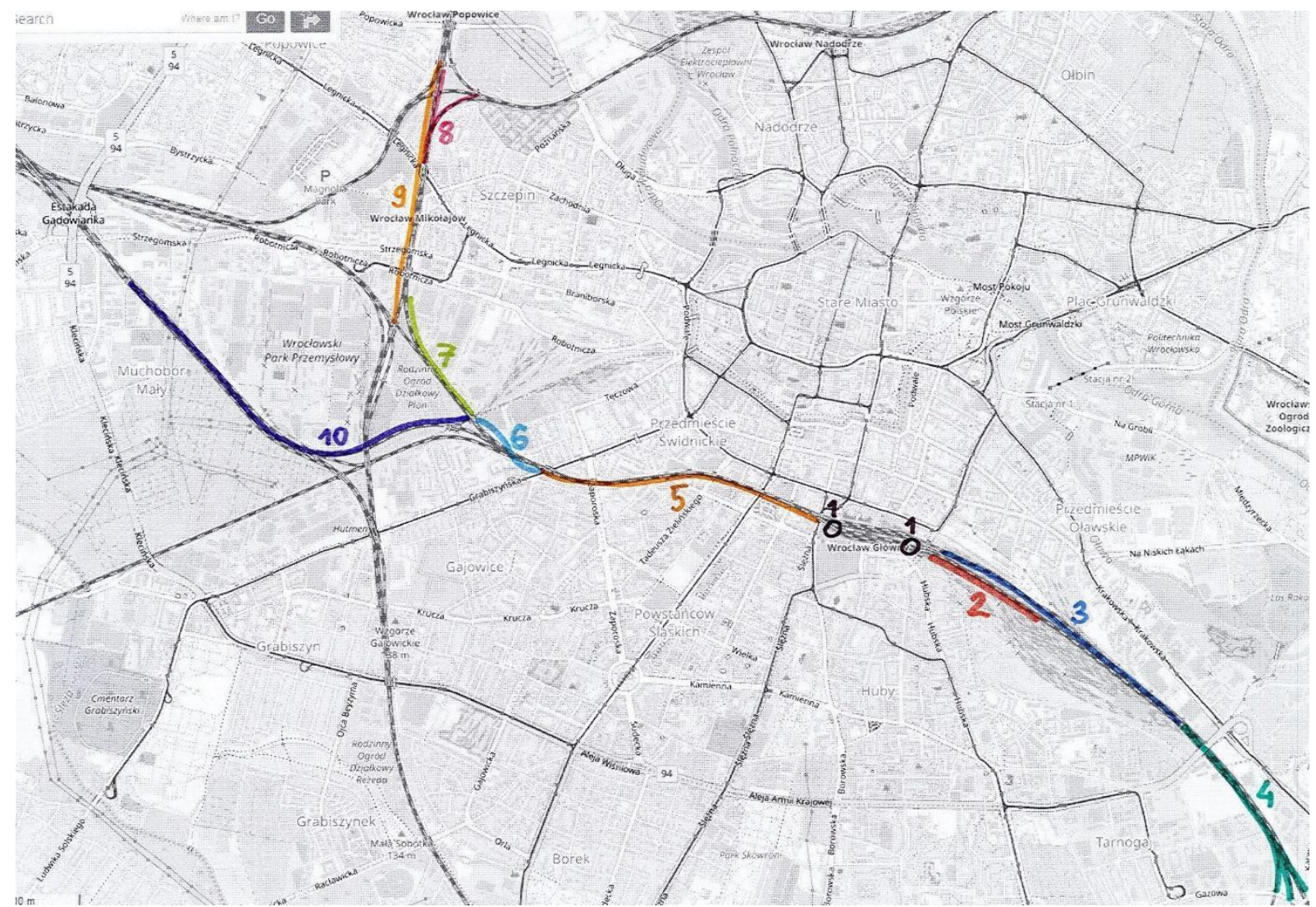

4. Infrastructural investments necessary to achieve the target 20-minute cycle for KA trains traffic [4]

The tasks numbered from 1 to 7 are intended to be carried out on the section from the Wroclaw Mikołajów via WG, to the planned new stop Wr. Armii Krajowej, a separate pair of tracks (in two opposite directions) intended only for the movement of KA trains, parallel to the corresponding pair of tracks intended for the movement of long-distance and KR trains. Such activities are necessary to create an attractive KA system, which is confirmed by numerous foreign and even domestic examples: the Warsaw cross-city line, the Tri-City LRT, the currently implemented "addition" of tracks on the section Kraków Gł. - Kraków Zabłocie. 
Another investment task necessary to achieve a 20-minute cycle time for KA trains is to make passes in appropriate locations on the lines that are planned to be left as single-track - both already in operation: 326 (to Trzebnica) and planned for reactivation: 292 (To Jelcz Miłoszyce via Swojczyce), 285 (to Świdnica) and 310 (to Niemcza).

In order to achieve a 20-minute cycle time for KA trains, in addition to the abovementioned infrastructural investments, it is also necessary to change the "philosophy" of arranging rail timetables on a national scale, because it is practically impossible (or even inadvisable) for KA trains in Poland to use only from its own tracks (independent of the traffic of long-distance trains and KR). Well, when constructing the timetable, first of all, the traffic of KA trains should be planned in all railway junctions with this type of traffic, and only then, the traffic of KR and long-distance trains should "fit" between these trains - that is exactly the opposite, as it is done today. With this method of arranging timetables, the principle of using cyclical departure times also for long-distance trains (which has been trying for some time) turns out to be beneficial - of course, provided that the tact used in the case of long-distance trains will be a multiple of the tact used for KA and KR trains.

\section{Sample tasks (1a and 5)}

The expansion of a flyover from a three-track section to a four-track section requires a decision regarding the location of an additional track, the allocation of track pairs for individual segments, and the location of stops. In the study [4], on the basis of the conducted analysis, it was recommended to build an additional track on the southern side of the existing tracks, to designate two southern tracks for KA, and to create island platforms at both planned stops (between a pair of tracks for KA). Among other things, the terrain conditions and the possibility of distributing train traffic at the ends of the diameter were taken into account, including in particular the introduction of KA on WG.

The introduction of KA on the WG from the west (task 1a, Figure 5) is conditioned by the non-interweaving of train relations of different segments. If it is assumed that the platform (or platforms) on the southern side of the station will be used to service KA, then it is reasonable to allocate the southern pair of tracks (red - new and blue - existing) on the flyover for KA.

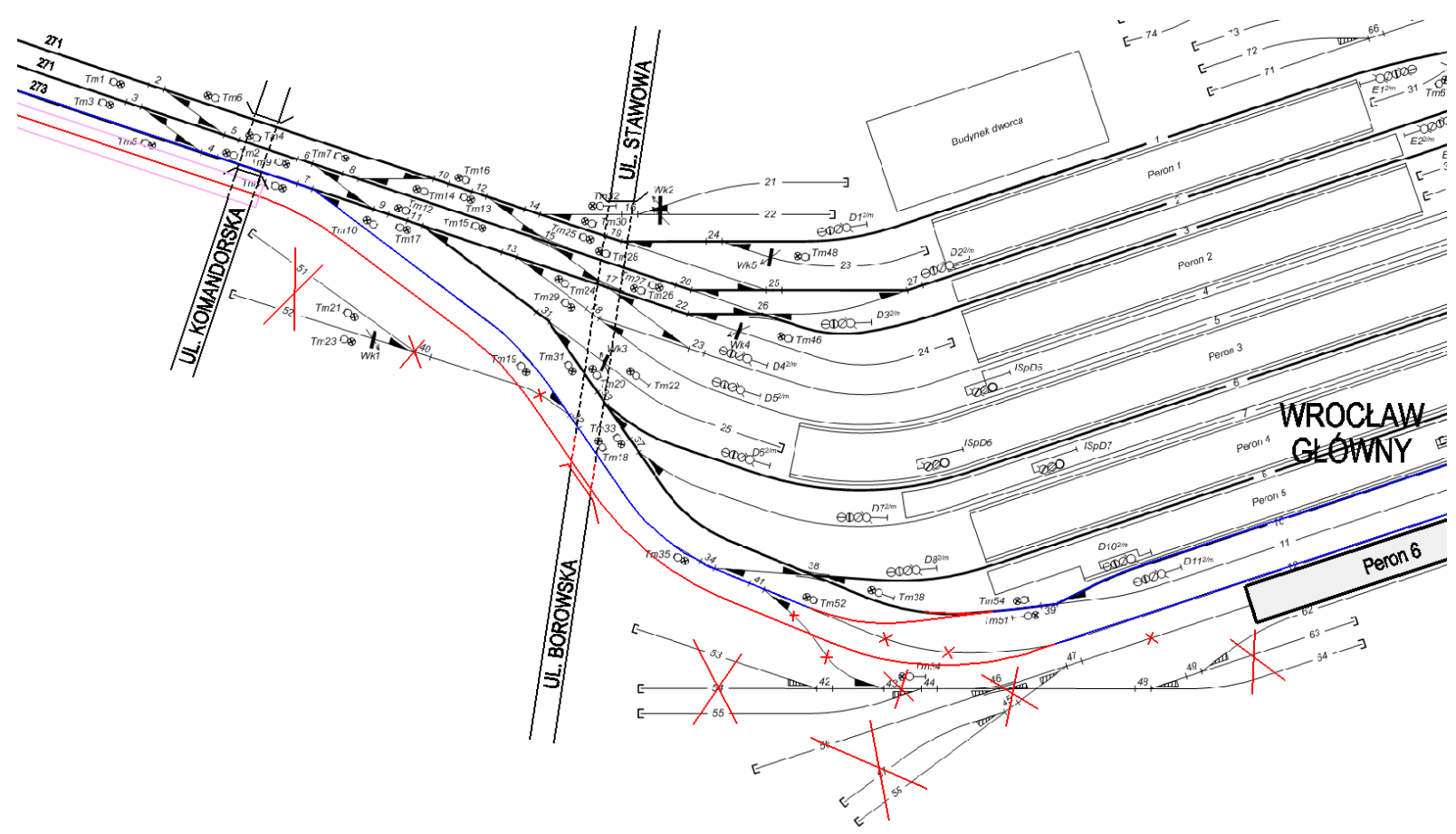

5. Details of task 1a [4] 
The issue of implementing new stops is described on the example of the location at Świdnicka Street (task 5, figure 6). In addition to spatial conditions (here to provide space for a stop and a new track - additionally moved away from today's flyover due to the platform), only one building will have to be demolished. In addition to the above, there are land reserves maintained due to the "longevity" of the concept of extending the flyover.

An important issue is also integration with other means of public (city) transport, in the case of the Świdnicka stop - with trams. Important routes connecting the south of the city with the center run across the railway diameter. Parallel to the diameter, among others, Circular route of line 0. It is proposed to build a new tram stop on the southern side of the flyover and thus expand the junction of tram stops at the Świdnicka - Piłsudskiego intersection. The appropriate configuration of the entrances to the railway platform will allow for convenient and quick transfers between trains and trams.

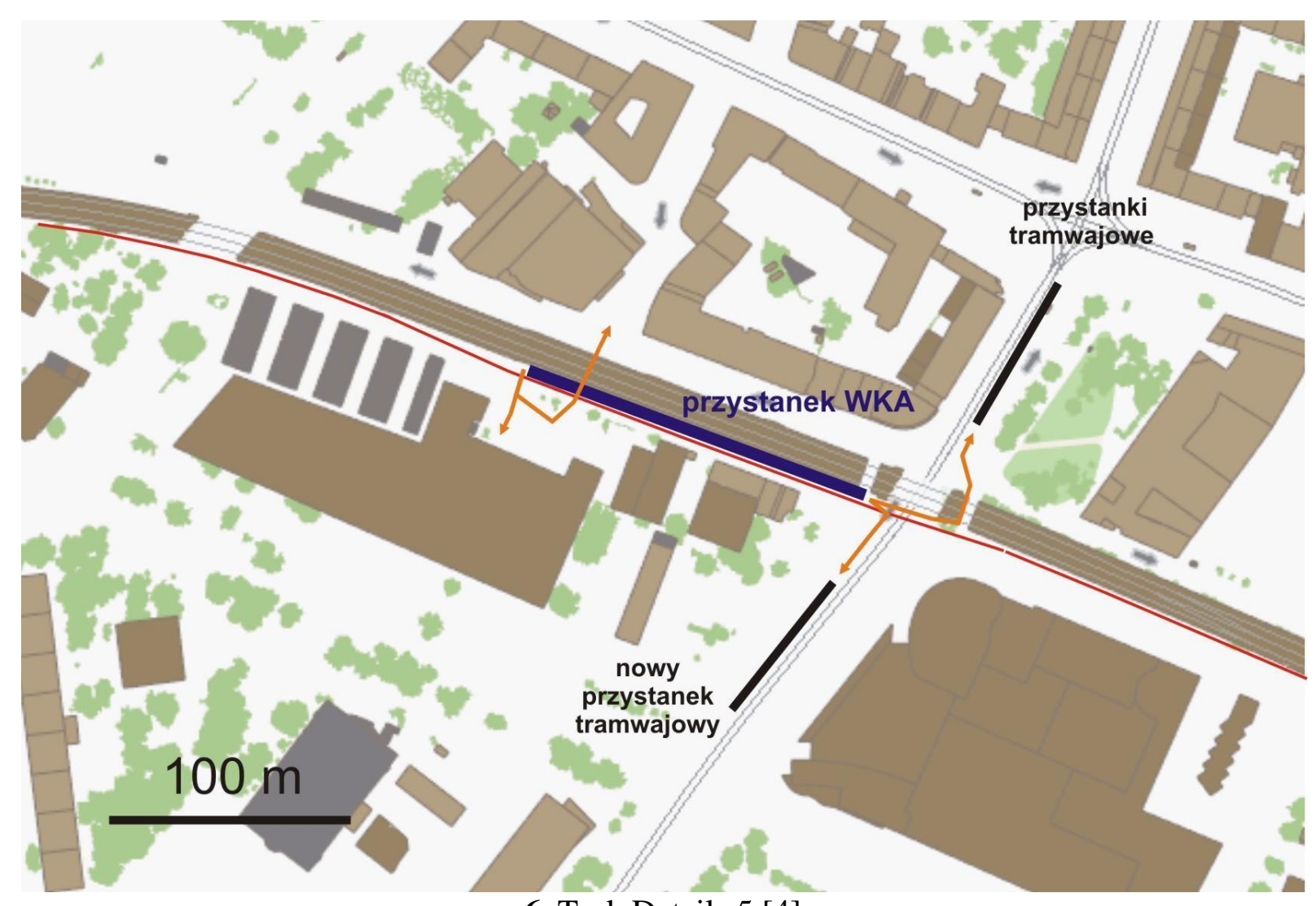

6. Task Details 5 [4]

\section{Summary}

Many investments are proposed for WWK. Due to the need to ensure adequate capacity in the central part of the node, activities related to the expansion of the central diameter section or the creation of a new diameter seem to be of key importance. The authors of the analysis cited here (and this article) see the need for both the expansion of the flyover and the construction (or even discussion) of a new (probably underground) diameter. The example of Leipzig or Munich shows that the commissioning of a double-track cross-city tunnel is associated, after some years of operation, with the exhaustion of the capacity [1] [11]. Thus, in the long run, more than one diameter will also be needed in the WWK. The potential for the intensification of AC transport in the Wrocław agglomeration is huge [6]. It is necessary to plan a number of investments with an indication of the sequence of implementation. In the opinion of the authors, the most important proposal is the extension of the flyover according to the principles presented in this article. The second (tunnel) diameter may be realized at a later time. The above is supported by 
economic aspects (the ratio of benefits to costs) and the potential duration of the investment and achieving its effects.

\section{Source materials}

[1] Bogdanowicz A., "W Monachium powstanie drugi tunel średnicowy S-Bahn", Rynek Kolejowy, 31.10.2016, https://www.rynek-kolejowy.pl/wiadomosci/w-monachiumpowstanie-drugi-tunel-srednicowy-sbahn-78817.html

[2] Korzeń M. „Koncepcja tunelu dla SKM we Wrocławiu”. Praca dyplomowa magisterska, opiekun I. Gisterek, Politechnika Wrocławska, 2021 r.

[3] Kruszyna M., „Propozycja wprowadzenia odcinków podziemnych w transporcie zbiorowym Wrocławia", Transport Miejski i Regionalny. 2015, nr 12

[4] Kruszyna M., Makuch J., Popiołek A., Gasz K. „Koncepcja rozwoju pasażerskiego transportu kolejowego w Aglomeracji Wrocławskiej poprzez uruchomienie Wrocławskiej Kolei Aglomeracyjnej. Raporty Wydziału Budownictwa Lądowego i Wodnego Politechniki Wrocławskiej. Raport SPR nr 32/2017

[5] Kruszyna M. „Koleje miejskie i regionalne w Polsce”, Monografia, Łódź: Księży Młyn Dom Wydawniczy, 2018

[6] Kruszyna M., "Investment challenges pertaining to the achievement of the goals of the Mobility Policy based on the analysis of the results of traffic surveys in Wroclaw", Archives of Civil Engineering, 3/2021

[7] Makuch J.: Dotychczasowe koncepcje uruchomienia we Wrocławiu kolei miejskiej lub aglomeracyjnej, XI Konferencja Naukowo-Techniczna „INFRASZYN”, Zakopane 18 20 kwietnia 2018

[8] Makuch J.: Działania niezbędne dla uruchomienia atrakcyjnego systemu kolei aglomeracyjnej na przykładzie Wrocławia, XI Konferencja Naukowo-Techniczna „INFRASZYN” Zakopane 18 - 20 kwietnia 2018

[9] Makuch J.: Stacja Wrocław Świebodzki jako element kolei aglomeracyjnej, XVII Ogólnopolska Konferencja Naukowo-Techniczna Nowoczesne Technologie i Systemy Zarządzania w Transporcie Szynowym, Zakopane 21 - 23 listopada 2018

[10] Opis Przedmiotu Zamówienia dla przetargu nieograniczonego na wykonanie dokumentacji przedprojektowej w ramach projektu: „Wstępne Studium Wykonalności dla Wrocławskiego Węzła Kolejowego wraz z opracowaniem Studium Wykonalności dla C-E 59 - odcinek Święta Katarzyna - Wrocław Brochów - Wrocław Muchobór/Wrocław Kuźniki”. Zadanie I: „Wstępne Studium Wykonalności dla Wrocławskiego Węzła Kolejowego" (WSW WrWK). PLK 2019

[11] Ryszka R. "City-Tunnel Leipzig - kulisy pewnego projektu”, Transport Publiczny, 21.12.2013, https://www.transport-publiczny.pl/wiadomosci/citytunnel-leipzig--kulisypewnego-projektu-cz-i-961.html 